Artikel Penelitian

\title{
Kopling Oksidatif Eugenol Menggunakan Ekstrak Enzim Peroksidase Akar Tanaman Sawi Hijau dan Uji Bioaktivitasnya
}

\author{
Bayu Ardiansah, Antonius Herry Cahyana*, Wahyudi Priyono Suwarso, Rianti Maryana, Siti Merly \\ Departemen Kimia, Fakultas Matematika dan IImu Pengetahuan Alam, Universitas Indonesia, Depok, Indonesia
}

\section{INFO ARTIKEL}

Sejarah artikel:

Revisi 15 Desember 2016

Diterima 30 Maret 2017

Tersedia online 09 Mei 2017

*Penulis korespondensi

Email: herrykim@ui.ac.id

\begin{abstract}
ABSTRAK
Peroxidase has been successfully extracted from root of mustard greens (Brassica juncea L. Czern). The root partially purified using ammonium sulfate. This enzyme was applied as biocatalyst to coupling reaction of eugenol. The product was analyzed optical properties and antioxidant activity. Structure elucidation of product was conducted by FTIR, UV-vis, and GC-MS. Protein content and specific activities of peroxidase were $0.747 \mathrm{mg} / \mathrm{mL}$ and $0.244 \mathrm{U} / \mathrm{mg}$, respectively. Peroxidase was applied as biocatalyst for green oxidative coupling reaction of eugenol to produce dimeric form of eugenol, an orange crystal ( $84 \%$ yields). The optical property of dimeric eugenol was Ra-configuration. Furthermore, biological activity of the product as antioxidant has been evaluated resulting in $\mathrm{IC}_{50}$ values of 32.14 and $42.43 \mathrm{ppm}$ for dimeric and monomeric eugenol, respectively.
\end{abstract}

Keywords: peroxidase, Brassica juncea, oxidative coupling, eugenol

Enzim peroksidasi telah berhasil diekstraksi dari akar sawi hijau (Brasicca juncea L. Czem). Pemurnian enzim peroksidase dilakukan secara parsial menggunakan amonium sulfat. Enzim ini diaplikasikan sebagai biokatalis pada reaksi kopling eugenol. Produk yang dihasilkan dianalisis sifat optik dan aktivitas antioksidannya. Elusidasi struktur produk dilakukan menggunakan instrumentasi FTIR, UV-Vis, dan GC-MS. Kadar protein dan aktivitas spesifik peroksidase masing-masing $0,747 \mathrm{mg} / \mathrm{mL}$ dan $0,244 \mathrm{U} / \mathrm{mg}$. Enzim peroksidase diaplikasi sebagai biokatalis reaksi kopling oksidatif senyawa eugenol untuk membentuk dimer eugenol berupa kristal kuning (hasil 84\%). Aktivitas optik dimer eugenol memiliki konfigurasi Ra. Nilai I $\mathrm{C}_{50}$ untuk dimer dan monomer eugenol adalah 32,24 dan 42,43 ppm, berturut-turut.

Kata Kunci: peroksidase, Brassica juncea, kopling oksidatif, eugenol

\section{Pendahuluan}

Eugenol merupakan senyawa bahan alam fenolik yang ditemukan dalam jumlah besar pada daun dan bunga cengkeh (Syzygium aromaticum) (Sudarma \& Ulfa, 2009). Senyawa tersebut telah dilaporkan memiliki beberapa aktivitas biologi seperti antijamur (Wang, Zhang, Chen, Fan, \& Shi, 2010), antibakteri (Catherine, Deepika, \& Negi, 2012), antioksidan (Mahboub \& Memmou, 2015; Nam \& Kim, 2013) dan antikanker (Abdel-Hameed et al., 2014; Yoo et al., 2005). Pada dekade terakhir, modifikasi eugenol dilakukan dengan 
tujuan mensintesis senyawa turunan eugenol dengan struktur molekul baru dan aktivitas biologi yang semakin beragam (Hidalgo et al., 2009; Mikhailovskii, Surikova, Limanskii, \& Vakhrin, 2012; Sadeghian, Seyedi, Saberi, Arghiari, \& Riazi, 2008). Salah satu tipe reaksi organik untuk memodifikasi senyawa fenolik seperti fenol, eugenol, isoeugenol, katekol, guaiakol dan timol adalah kopling oksidatif dengan bantuan katalis kimia (Barve et al., 2015) maupun biokatalis (Cheng \& Harper Jr, 2012).

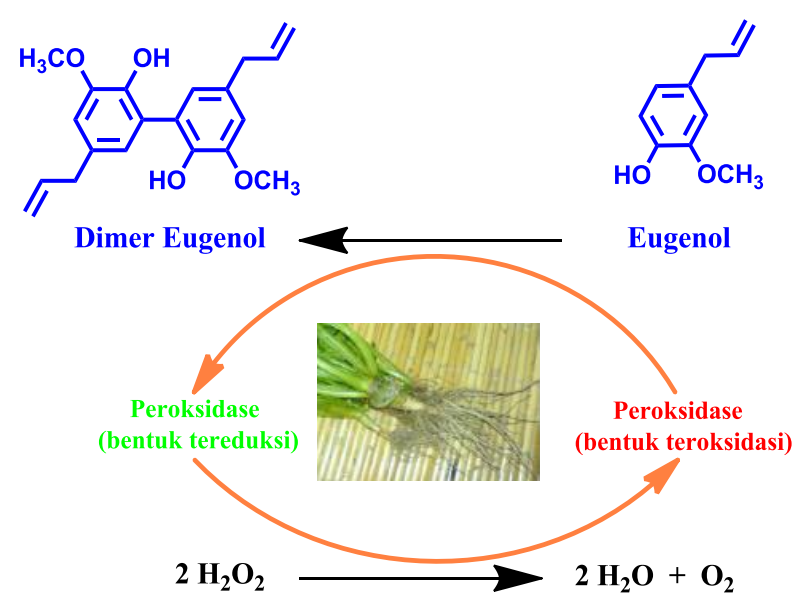

Gambar 1. Reaksi kopling oksidatif eugenol menggunakan peroksidase

Biokatalis lebih diminati beberapa peneliti untuk transformasi senyawa organik karena bersifat ramah lingkungan, tersedia dalam jumlah memadai di alam dan memiliki selektivitas yang baik (Luan \& Chen, 2014; Taboada-Puig et al., 2016). Berkaitan dengan reaksi kopling oksidatif, enzim peroksidase adalah salah satu biokatalis kelas oksidoreduktase yang dapat memfasilitasi penggabungan molekul fenolik menjadi bentuk dimer maupun polimer (Onsa, bin Saari, Selamat, \& Bakar, 2004). Pada penelitian terdahulu, guaiakol dapat mengalami dimerisasi yang dikatalisis oleh enzim peroksidase dari Brassica oleracea var alboglabra (Anita, Widiyarti, \& Abbas, 2014). Selain itu, polimerisasi fenolik menjadi 3,14'-bihispidinil juga pernah dilakukan (Lee \& Yun, 2008). Berdasarkan hal tersebut, pada penelitian ini bertujuan untuk mengaplikasikan enzim peroksidase dari akar tanaman sawi hijau (Brassica juncea L. Czern) sebagai biokatalis pada reaksi kopling oksidatif eugenol dengan bantuan hidrogen peroksida. Selain itu, akan dipelajari pula sifat optik dan aktivitas antioksidannya.

\section{Bahan dan metode}

\subsection{Bahan}

Bahan utama adalah akar sawi hijau (Brassica juncea L. Czern) dari perkebunan Bulevar Hijau, Bekasi. Bahan lain yang digunakan meliputi 4aminoantipirin (Sigma-Aldrich), amonium sulfat, bovine serum albumin (Sigma-Aldrich), eugenol (Merck), DPPH (difenilpikrilhidrazil) (SigmaAldrich), fenol (Merck), hidrogen peroksida 30\% (Merck) dan pereaksi Folin (Sigma-Aldrich).

\subsection{Isolasi dan pemurnian parsial peroksidase}

Sebanyak $350 \mathrm{~g}$ potongan akar sawi hijau ditambahkan larutan bufer K-fosfat $\mathrm{pH} 7$ kemudian diblender dalam keadaan dingin $\left(0-5^{\circ} \mathrm{C}\right)$. Setelah itu, homogenat disaring dengan kain katun dan filtrat disentrifugasi dengan kecepatan $1100 \mathrm{rpm}$ selama 20 menit. Supernatan ekstrak enzim kasar dipisahkan dari residu padat.

Pemurnian ekstrak kasar dilakukan secara fraksinasi (fraksi I - III) menggunakan amonium sulfat dengan tingkat kejenuhan $0-30 \%, 30-50 \%$ dan $50-70 \%$ (b/v). Penambahan garam dilakukan secara sedikit demi sedikit dalam keadaan dingin $\left(0-5^{\circ} \mathrm{C}\right)$ di atas pengaduk magnet selama 2 jam. Larutan didiamkan selama satu malam dan endapan yang terbentuk (ekstrak enzim fraksi I) dipisahkan dan dilakukan pemurnian dengan konsentrasi amonium sulfat yang lebih pekat. Ekstrak kasar enzim yang digunakan sebagai katalis pada penelitian ini adalah ekstrak kasar peroksidase fraksi III, yaitu hasil pemurnian menggunakan amonium sulfat $50-70 \%(b / v)$.

Penentuan kadar protein enzim dilakukan menggunakan metode Lowry (Redmile-Gordon, Armenise, White, Hirsch, \& Goulding, 2013). Aktivitas spesifik peroksidase diukur menggunakan pereaksi 4-aminoantipirin dan serapan diamati pada $510 \mathrm{~nm}$ menggunakan spektrofotometer UVVis. Sebanyak 1,4 mL larutan 4aminoantipirin/fenol dimasukkan ke dalam tabung reaksi yang berisi $1,5 \mathrm{~mL}$ hidrogen peroksida $0,0017 \mathrm{M}$ dan dikocok. Campuran tersebut ditambahkan 0,1 mL ekstrak enzim kasar dan dibiarkan bereaksi selama 1 menit. Reaksi tersebut dihentikan dengan cara memanaskan tabung reaksi pada $100^{\circ} \mathrm{C}$ selama 3 menit. Aktivitas enzimatik dinyatakan sebagai unit aktivitas (U/mg), dimana $\mathrm{U} / \mathrm{mg}$ adalah serapan pada $510 \mathrm{~nm}$ dibagi dengan (6,58 $\times$ kadar protein, $\mathrm{mg} / \mathrm{mL})$. 


\subsection{Reaksi kopling oksidatif eugenol}

Ekstrak kasar enzim peroksidase sebanyak 4 $\mathrm{mL}$ dimasukkan dalam gelas kimia, kemudian ditambah $1 \mathrm{~mL}$ eugenol dan 1,67 mL hidrogen peroksida $30 \%$. Campuran diaduk selama 30 menit pada suhu $0-5^{\circ} \mathrm{C}$. Produk berwarna diekstraksi menggunakan etil asetat. Setelah penguapan, padatan yang terbentuk dimurnikan dengan teknik kromatografi kolom dengan pelarut $n$-heksana:etil asetat dengan perbandingan 9:1, 8:2 dan 7:3.

\subsection{Penentuan sudut rotasi optik}

Sebanyak $5 \mathrm{mg}$ produk dimerisasi dilarutkan dengan etil asetat pada labu ukur $25 \mathrm{~mL}$ dan diencerkan sampai tanda batas. Selanjutnya larutan dimasukkan ke kuvet polarimeter $2 \mathrm{dm}$ yang telah dilengkapi lampu natrium. Rotasi optik dibaca sebagai sudut yang memutar ke kanan atau ke kiri dari bidang normal.

\subsection{Uji aktivitas antioksidan}

Aktivitas antioksidan diukur menggunakan metode penangkapan radikal bebas DPPH dengan modifikasi (Bandgar, Gawande, Bodade, Gawande, \& Khobragade, 2009). Sebanyak $1 \mathrm{~mL}$ DPPH 0,001 $M$ ditambah dengan $1 \mathrm{~mL}$ sampel dengan berbagai variasi konsentrasi (25, 50 dan 100 ppm), kemudian diencerkan dengan metanol hingga volume total menjadi $5 \mathrm{~mL}$. Serapan/absorbansi (A) larutan uji diukur pada $517 \mathrm{~nm}$ dan dicatat hasilnya setiap 5 menit selama 35 menit. Larutan kontrol digunakan DPPH dalam metanol tanpa penambahan sampel. Aktivitas antioksidan dalam bentuk persen inhibisi diukur dengan Persamaan 1.

Inhibisi (\%) $=\frac{\text { A kontrol - A sampel }}{\text { A kontrol }} \times 100 \%$

\section{Hasil dan pembahasan}

\subsection{Isolasi dan penentuan aktivitas peroksidase}

Proses isolasi enzim peroksidase dilakukan pada suhu rendah dan pada $\mathrm{pH} 7$ yang bertujuan untuk mencegah terjadinya degradasi proteolitik yang disebabkan oleh enzim-enzim protease. Proses pemisahan sel debris dilakukan penyaringan dan sentrifugasi. Supernatan hasil sentrifugasi disebut ekstrak kasar (EK).

Peroksidase merupakan suatu protein enzim yang mempunyai variasi kelarutan yang dipengaruhi oleh konsentrasi garam. Karakter ini melibatkan interaksi spesifik antara muatan rantai samping dan ion-ion dalam larutan. Penambahan amonium sulfat terhadap ekstrak kasar (EK) menyebabkan adanya proses salting out, yaitu berkurangnya kelarutan suatu protein karena penambahan suatu zat (garam). Protein enzim yang mengalami proses salting out akan mengendap tetapi strukturnya tidak terdenaturasi. Hal ini yang menjadi dasar pemurnian peroksidase menggunakan metode penambahan amonium sulfat dengan berbagai tingkat konsentrasi larutan garam.

Fraksinasi dilakukan untuk memisahkan enzim peroksidase dari ekstrak kasar (EK) dengan cara pengendapan berdasarkan bobot molekulnya. Protein dengan bobot molekul yang lebih besar akan mengendap terlebih dahulu, diikuti protein dengan bobot molekul yang lebih ringan. Proses fraksinasi dilakukan selama 2 jam pada suhu $4^{\circ} \mathrm{C}$ dengan penambahan garam amonium sulfat sesuai persentase kejenuhan sedikit demi sedikit. Endapan yang diperoleh dari hasil fraksinasi ke-3 (pemurnian dengan amonium sulfat $50-70 \%$ ) kemudian disuspensikan kembali dalam larutan bufer K-fosfat pH 7 sampai larut. Ekstrak enzim peroksidase fraksi ini disebut peroksidase EK-III dan digunakan untuk tahap selanjutnya.

Aktivitas enzim diukur dengan 4-aminoantipirin dengan fenol sebagai substrat dan hidrogen peroksida sebagai penerima elektron (Metelitza, Karasyova, Grintsevich, \& Thorneley, 2004). Pada tahap inisiasi, enzim peroksidase dalam bentuk tereduksi akan memberikan elektron kepada hidrogen peroksida. Hal ini mengakibatkan penguraian hidrogen peroksida menjadi air dan oksigen. Di sisi lain, peroksidase berubah menjadi enzim peroksidase dalam bentuk yang teroksidasi (Gambar 2, Persamaan 2). Enzim peroksidase dalam bentuk teroksidasi akan mengoksidasi fenol dan 4-aminoantipirin (substrat) sehingga menghasilkan bentuk radikalnya, sedangkan peroksidase menjadi bentuk teroksidasi lainnya yang ditunjukkan pada Persamaan 3 dan 3' (Gambar 2). Pada tahap terminasi, radikal fenol dan 4-aminoantipirin akan bergabung membentuk senyawa adduct kuinonimina yang berwarna merah darah (Gambar 2, Persamaan 5"). Perubahan intensitas warna larutan diukur dengan UV-Vis pada $510 \mathrm{~nm}$ dan dihasilkan serapan 1,2. Berdasarkan hasil pengukuran kadar protein didapatkan bahwa ekstrak peroksidase EK-III mengandung $0,747 \mathrm{mg} / \mathrm{mL}$ sehingga didapatkan aktivitas spesifik peroksidase sebesar 0,244 U/mg. 


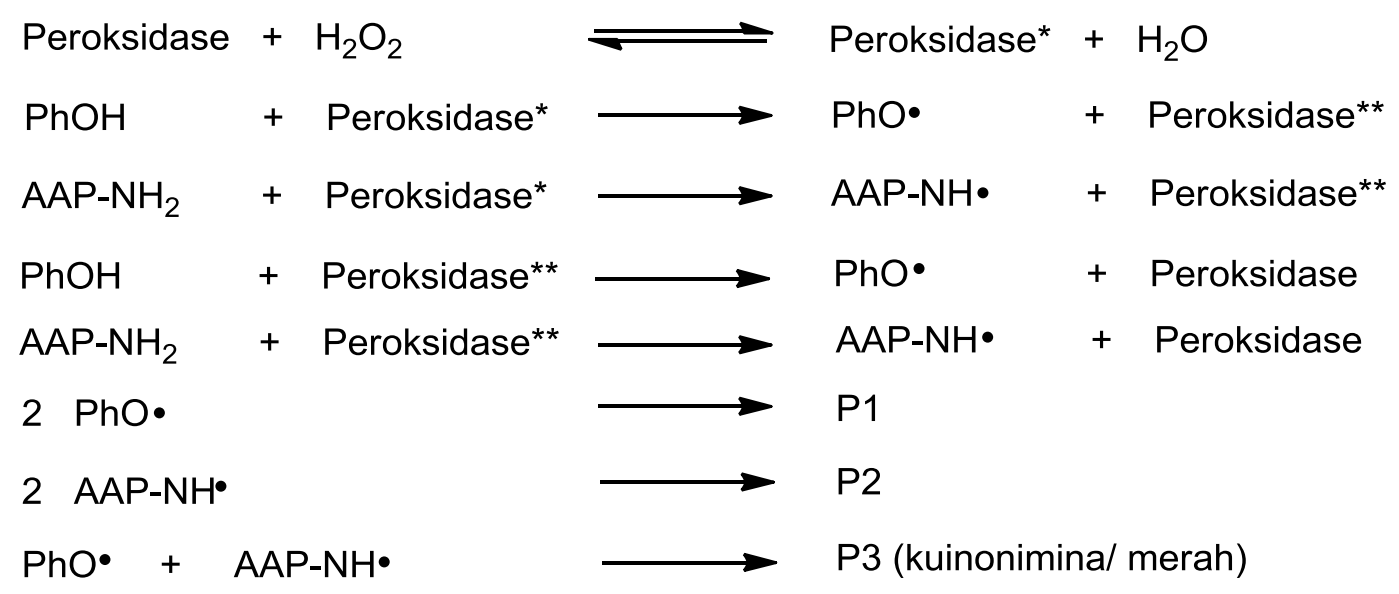

Gambar 2. Reaksi-reaksi yang terlibat pada penentuan aktivitas peroksidase

\subsection{Reaksi kopling oksidatif eugenol}

Penambahan peroksidase pada campuran eugenol dan hidrogen peroksida menyebabkan terjadinya proses dimerisasi yang ditandai dengan pembentukan larutan berwarna kuning pekat. Setelah dimurnikan menggunakan kromatografi kolom dengan meningkatkan kepolaran fasa gerak secara bertahap kemudian diuapkan, didapatkan kristal berwarna kuning dengan titik leleh 105$106^{\circ} \mathrm{C}$. Analisis dengan FTIR menunjukkan adanya vibrasi gugus $\mathrm{OH}$ pada $3448 \mathrm{~cm}^{-1}$. Serapan pada 3051 dan $2990 \mathrm{~cm}^{-1}$ menandakan bahwa pada senyawa terdapat $\mathrm{C}-\mathrm{H} \mathrm{sp}^{2}$ aromatik dan dan $\mathrm{C}-\mathrm{H}$ $\mathrm{sp}^{3}$ dari gugus metoksi. Puncak yang tajam di daerah sekitar $1540 \mathrm{~cm}^{-1}$ mengindikasikan vibrasi dari cincin aromatik.

Konfirmasi keberhasilan reaksi dimerisasi (kopling oksidatif) eugenol dilakukan dengan menggunakan GC-MS. Berdasarkan kromatogram GC dihasilkan puncak tertinggi pada waktu retensi 16,15 menit dengan luas area 83,64\% (Gambar 3). Setelah dilakukan pengukuran $M S$, muncul fragmen utama dengan $\left[\mathrm{M}^{+}\right]$sebesar $326 \mathrm{~g} / \mathrm{mol}$. Nilai ini merupakan hasil penggabungan 2 molekul eugenol (berat molekul eugenol $164 \mathrm{~g} / \mathrm{mol}$ ) yang terjadi melalui $\mathrm{C}-\mathrm{C}$ dimerisasi dengan mekanisme radikal bebas.

Konsekuensi dari dimerisasi molekul eugenol akan menambah jumlah ikatan rangkap yang terkonjugasi dalam senyawa produk. Sesuai dengan teori orbital molekul, semakin banyak ikatan rangkap akan memperkecil perbedaan energi orbital HOMO dan LUMO sehingga transisi elektronik dapat diamati pada panjang gelombang yang lebih besar. Hal ini dikonfirmasi dari pengukuran panjang gelombang maksimum untuk eugenol dan dimer eugenol. Monomer eugenol memberikan serapan maksimum pada $302 \mathrm{~nm}$ sedangkan bentuk dimernya pada $312 \mathrm{~nm}$.

Produk reaksi diukur dengan polarimeter yang bertujuan mempolarisasi cahaya dan mengukur sudut rotasi optik spesifik bidang polarisasi cahaya oleh suatu senyawa optik aktif. Dimer eugenol termasuk kelompok turunan senyawa bifenil yang mempunyai sifat kiralitas yang disebabkan oleh sumbu (chiral axis). Pada sampel kristal $(0,0002$ $\mathrm{g} / \mathrm{mL}$ ) yang diukur mempunyai a pengukuran sebesar +0,1. Polarimeter yang digunakan mempunyai panjang tabung $20 \mathrm{~cm}$ sehingga besarnya sudut rotasi spesifik dimer eugenol terhitung sebesar $+25^{\circ}$. Berdasarkan data tersebut dapat disimpulkan bahwa molekul produk reaksi memutar bidang polarisasi ke kanan (Ra) (Gambar 4).

\subsection{Uji aktivitas antioksidan}

Senyawa fenolik merupakan salah satu sumber antioksidan yang menghambat reaksi radikal dengan cara bereaksi dengan radikal bebas tersebut, memberikan hidrogen, dan membentuk radikal bebas fenolik yang terstabilkan oleh resonansi. Eugenol dan dimer eugenol termasuk senyawa fenolik yang berpotensi mendonorkan atom hidrogen untuk menetralkan radikal bebas. Metode yang dipakai pada penentuan aktivitas antioksidan adalah metode penangkapan radikal DPPH (difenil pikrilhidrazil). 

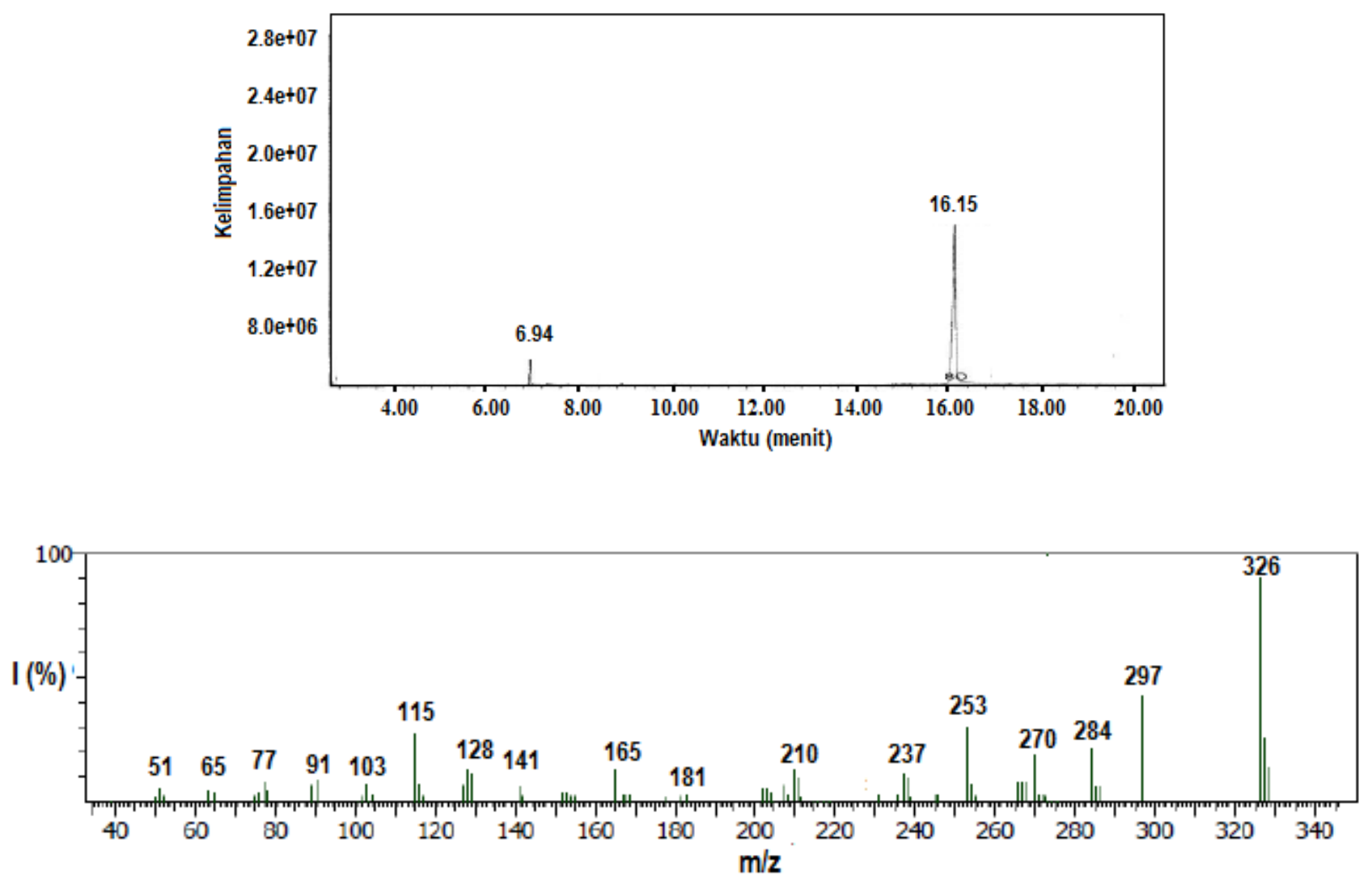

Gambar 3. Kromatogram GC-MS pada analisis dimer eugenol
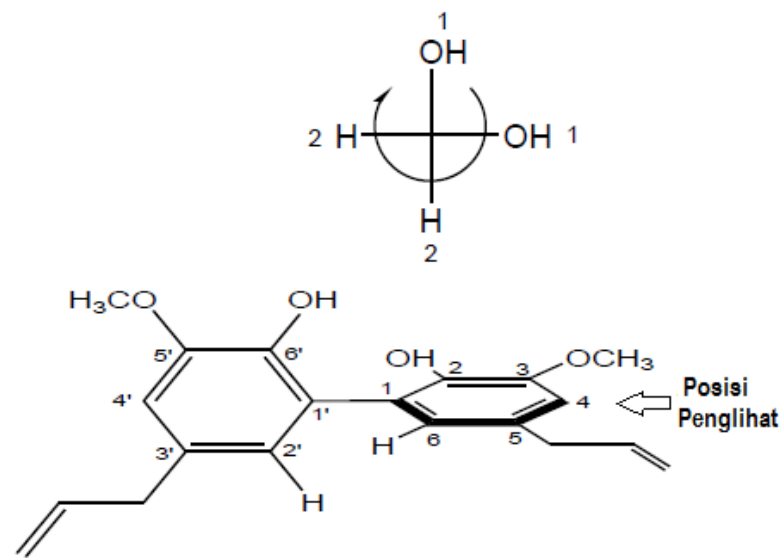

Gambar 4. llustrasi konfigurasi Ra dimer eugenol

Senyawa DPPH adalah senyawa radikal yang memberikan warna ungu dengan serapan maksimum pada $517 \mathrm{~nm}$. Senyawa yang dapat mendonorkan atom hidrogen seperti fenolik akan bereaksi untuk menetralkan senyawa model DPPH radikal yang menyebabkan berkurangnya intensitas warna ungu DPPH dan berangsur berubah menjadi kuning. Pengurangan intensitas warna ungu menjadi dasar pengukuran aktivitas antioksidan secara kuantitatif senyawa eugenol dan dimer eugenol pada penelitian ini.
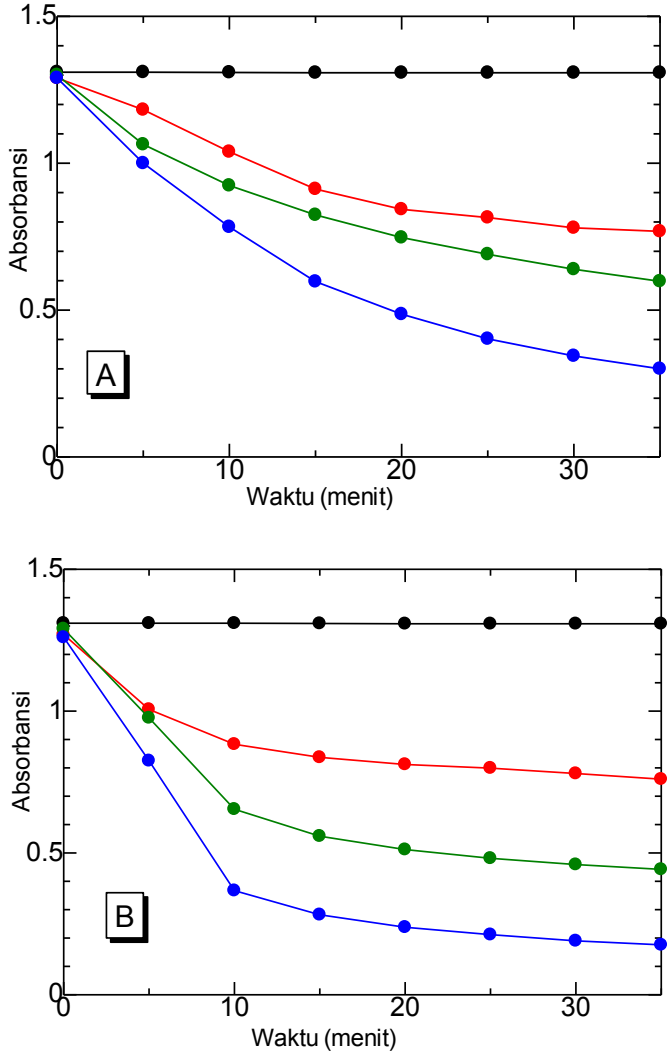

Gambar 5. Profil absorbansi (pada $517 \mathrm{~nm}$ ) akibat penambahan sampel $(A)$ eugenol dan (B) dimer eugenol dengan $-\bullet$ (larutan kontrol), - (25 ppm), $\rightarrow(50$ ppm) dan $\rightarrow-(100$ ppm $)$ 
Aktivitas antioksidan eugenol dan dimer eugenol ditampilkan pada Gambar 5. Berdasarkan gambar tersebut dapat dilihat bahwa kedua senyawa tersebut bersifat antioksidan. Hal ini ditunjukkan dengan adanya pengurangan nilai serapan DPPH yang mengindikasikan bahwa senyawa dapat menetralkan radikal. Semakin besar konsentrasi sampel yang ditambahkan maka akan menyebabkan penangkapan (netralisasi) radikal bebas yang semakin besar pula.

Kemampuan inhibisi $\left(\mathrm{IC}_{50}\right)$ dimer pada 35 menit sebesar 32,14 ppm, sedangkan eugenol mempunyai nilai inhibisi sebesar $42,43 \mathrm{ppm}$. Hal tersebut menunjukkan bahwa dimer eugenol lebih aktif sebagai zat antioksidan dibandingkan dengan eugenol. Aktivitas dimer eugenol yang lebih baik dimungkinkan karena dalam struktur molekulnya mengandung dua atom hidrogen fenolik sehingga secara kualitatif akan mendonorkan atom hidrogen lebih banyak dibandingkan eugenol dalam menetralkan radikal bebas.

\section{Kesimpulan}

Enzim peroksidase dari akar sawi hijau memiliki kandungan protein $0,747 \mathrm{mg} / \mathrm{mL}$ dan aktivitas spesifik 0,244 U/mg. Enzim ini diaplikasikan pada reaksi kopling eugenol sebagai dan dihasilkan produk dimer eugenol. Dimer eugenol memiliki sifat optik berupa konformasi Ra. Aktivitas antioksidan dimer eugenol dan monomer eugenol masing-masing memiliki nllai I $\mathrm{C}_{50}$ sebesar 32,24 dan 42,43 ppm.

Ekstrak kasar enzim peroksidase dapat dimanfaatkan sebagai biokatalis murah pada transformasi oksidatif eugenol menjadi eugenol yang dilangsungkan dalam pelarut air. Reaksi yang ramah lingkungan dengan dikatalisis peroksidase sangat menjanjikan untuk transformasi organik di masa depan dalam rangka mensintesis struktur senyawa baru yang aktif secara biologi.

\section{Ucapan terima kasih}

Terima kasih diucapkan kepada DRPM Universitas Indonesia atas proyek penelitian PITTA 2016.

\section{Daftar pustaka}

Abdel-Hameed, E.-S. S., Bazaid, S. A., Al-Zahrani, O., El-Halmouch, Y., El-Sayed, M. M., \& ElWakil, E. (2014). Chemical composition of volatile components, antimicrobial and anticancer activity of n-hexane extract and essential oil from Trachyspermum ammi $L$. seeds. Oriental Journal of Chemistry, 30(4), 1653-1662.

Anita, Y., Widiyarti, G., \& Abbas, J. (2014). Synthesis and elucidation structure of $\mathrm{O}$ para dehydroguaiacol prepared by crude of Brassica oleracea var alboglabra peroxdase-catalyzed oxidation. Journal of Applied Pharmaceutical Science, 4(4), 62 65

Bandgar, B. P., Gawande, S. S., Bodade, R. G., Gawande, N. M., \& Khobragade, C. N. (2009). Synthesis and biological evaluation of a novel series of pyrazole chalcones as anti-inflammatory , antioxidant and antimicrobial agents. Bioorganic \& Medicinal Chemistry, 17(24), 8168-8173. http://doi.org/10.1016/j.bmc.2009.10.035.

Barve, B. D., Wu, Y.-C., El-Shazly, M., Korinek, M., Cheng, Y.-B., Wang, J.J., \& Chang, F.-R. (2015). Copper-catalyzed selective C-O bond formation by oxidative $\mathrm{a}-\mathrm{C}(\mathrm{sp} 3)-\mathrm{H} / \mathrm{O}$ $\mathrm{H}$ coupling between ethers and salicylaldehydes. Tetrahedron, 71(15), 2290-2297.

Catherine, A. A., Deepika, H., \& Negi, P. S. (2012). Antibacterial activity of eugenol and peppermint oil in model food systems. Journal of Essential Oil Research, 24(5), 481-486.

Cheng, W., \& Harper Jr, W. F. (2012). Chemical kinetics and interactions involved in horseradish peroxidase-mediated oxidative polymerization of phenolic compounds. Enzyme and Microbial Technology, 50(3), 204-208.

Hidalgo, M. E., De la Rossa, C., Carrasco, H., Cardona, W., Gallardo, C., \& Espinoza, L. (2009). Antioxidant capacity of eugenol derivatives. Quimica Nova, 32(6), 14671470.

Lee, I. K., \& Yun, B. S. (2008). Peroxidasemediated formation of the fungal polyphenol 3,14'-bihispidinyl. Journal of Microbiology and Biotechnology, 18(1), 107-109.

Luan, J., \& Chen, M. (2014). Preliminary biodegradation of cygon with lignin peroxidase as biocatalyst and further removal of cygon with carbon nanotube$\mathrm{Gd} 2 \mathrm{YbSbO} 7$ as nanocatalyst. Journal of Biotechnology, 185(Supplement), S104. 
Mahboub, R., \& Memmou, F. (2015). Antioxidant activity and kinetics studies of eugenol and 6-bromoeugenol. Natural Products Research, 29(10), 966-971.

Metelitza, D. I., Karasyova, E. I., Grintsevich, E. E., \& Thorneley, R. N. F. (2004). Peroxidasecatalyzed co-oxidation of $3,3^{\prime}, 5,5^{\prime}$ tetramethylbenzidine in the presence of substituted phenols and their polydisulfides. Journal of Inorganic Biochemistry, 98, 1-9.

Mikhailovskii, A. G., Surikova, O. V., Limanskii, E. S., \& Vakhrin, M. I. (2012). Synthesis of isoquinoline alkaloid derivatives from eugenol. Chemistry Natural Compounds, 48(2), 285-287.

Nam, H., \& Kim, M.-M. (2013). Eugenol with antioxidant activity inhibits MMP-9 related to metastasis in human fibrosarcoma cells. Food and Chemical Toxicology, 55, 106112.

Onsa, G. H., bin Saari, N., Selamat, J., \& Bakar, J. (2004). Purification and characterization of membrane-bound peroxidases from Metroxylon sagu. Food Chemistry, 85(3), 365-376.

Redmile-Gordon, M. A., Armenise, E., White, R. P., Hirsch, P. R., \& Goulding, K. W. T. (2013). A comparison of two colorimetric assays, based upon Lowry and Bradford techniques, to estimate total protein in soil extracts. Soil Biology and Biochemistry, 67, 166-173.
Sadeghian, H., Seyedi, S. M., Saberi, M. R., Arghiari, Z., \& Riazi, M. (2008). Design and synthesis of eugenol derivatives as potent 15-lipoxygenase inhibitors. Bioorganic \& Medicinal Chemistry, 16(2), 890-901.

Sudarma, I. M., \& Ulfa, M. (2009). Synthesis of 4allyl-2-methoxy-6-aminophenol from natural eugenol. Indonesian Journal of Chemistry, 9(1), 84-88.

Taboada-Puig, R., Eibes, G., Lloret, L., Lu-Chau, T. A., Feijoo, G., Moreira, M. T., \& Lema, J. M. (2016). Fostering the action of versatile peroxidase as highly efficient biocatalyst for the removal of endocrine disrupting compounds. New Biotechnology, 33(1), 187-195.

Wang, C., Zhang, J., Chen, H., Fan, Y., \& Shi, Z. (2010). Antifungal activity of eugenol against Botrytis cinerea. Tropical Plant Pathology, 35(3), 137-143.

Yoo, C.-B., Han, K.-T., Cho, K.-S., Ha, J., Park, H.J., Nam, J.-H., ... Lee, K.-T. (2005). Eugenol isolated from the essential oil of Eugenia caryophyllata induces a reactive oxygen species-mediated apoptosis in $\mathrm{HL}-$ 60 human promyelocytic leukemia cells. Cancer Letters, 225(1), 41-52. 